\title{
MJN RELATIONSHIP BETWEEN FAMILY BELIEFS ABOUT MENTAL HEALTH WITH FIRST ACTION FOR SEEKING MENTAL HEALTH TREATMENT
}

\author{
Fathra Annis Nauli*, Geby Swarty and Reshalia \\ Faculty of Nursing, Universitas Riau, Indonesia \\ *Corresponding Author's Email:fathranauli@yahoo.com
}

\begin{abstract}
The lack of seeking treatment for mental disorder was related to the community beliefs about mental disorder. People believe that mental disorders are caused as the victims are possessed and perform witchcraft. So, people seek for help from person with supernatural ability. This study aimed to determine the relationship between family beliefs about mental health and the first step in seeking treatment for mental disorders. The design of this study is quantitative research with cross sectional approach. The sample of this study consisted of 47 family with mental health patients in Kampar Kiri Public Health Center which was selected by using total sampling technique. The data were collected by using family health beliefs about mental health questionnaire and seeking formal treatment questionnaire that had tested its validity and reliability. The univariate analysis used to determine the frequency of distribution and bivariate analysis was done using chi-square test with Kolmogorov Smirnov as alternative test. Univariate result showed that majority of respondents believe that mental health is supernatural $(61.7 \%)$ with the first action in seeking treatment for mental disorders is people with supernatural ability (53. $2 \%)$. The result of bivariate analysis showed $p$ value $(0.000)<\alpha(0.05)$. So, it can be concluded that there is a significant relationship between patients' family beliefs about mental health towards the first action in seeking treatment for mental disorders in Kampar Kiri Health Center.
\end{abstract}

Keywords: Mental Disorder, Community Beliefs, The First Act of Treatment

\section{INTRODUCTION}

Based on the results of the Basic Health Research, the prevalence of severe mental disorders in Riau Province was 0.9 per mile or per 1000 population $(5,850$ residents of $6,500,971$ Riau population) with the highest prevalence of mental disorders in Kampar Regency which was $2.4 \%$. Mental disorders are mental impairment that can affect the function of someone's life (Nasir \& Muhith, 2015). Someone with mental disorder must immediately get treatment because the delay of treatment will harm the sufferer, family and community (Yosep, 2011).

The lack of seeking treatment for mental disorders is also due to people beliefs about mental disorders. The beliefs and attitudes of different groups are influenced by different factors. Due to the belief about mental health problems the treatment of mental health problems is not at par with the current scientific development, and it will lead to negative attitudes among the community
(Angermeyer et al., 2006).

The background of treatment given by the family to mental health patients influenced by community beliefs about mental health. One of the management is by doing restraints or stocks. The purpose is to prevent someone from harming themselves or others so it can prevent serious trauma to the patient or others (Kirkby, 2017).

The views of family and society, about people with mental disorders, are always identified as mad and possessed by demons. Community belief that demons are cause of mental disorder. The family usually alienates family members who have mental disorders, because if they show symptoms of mental disorders people will think they are possessed. As a result, they will be shunned, mocked, excluded from normal society (Videbeck, 2011).

Based on mental health data in Kampar Kiri Public Health Center in 2018, there were 47 people with mental disorders and only $10 \%$ of the families of patients seek 
treatment to health facility. Preliminary survey was conducted by researchers on November 14,2018 in Kampar Kiri Health Center by interviewing 10 families with mental disorders patients ( 2 people in Lipat Kain Utara, 2 people in Teluk Paman Timur, and 6 people in Kuntu Village). About 8 people suffering from mental disorders said they have been suffered mental disorder more than 5 years and they never been taken to a mental hospital to check their mental condition or to a psychologist. They just go to shaman and ustadz, because the family believes that mental disorder is a disease caused by demon or curse.

The results of interviews with Kampar Kiri Community Health Center staff found that there were 5 families with mental patients who were isolated or confined from family members. This was because mental patients had rampaged and endangered others. Family member abandoned mental disorders patient because they are ashamed of the family members who suffer mental disorders.

So, in the present study the researcher finds out the relationship of family beliefs about mental health to the option of seeking treatment for mental disorders patients.

\section{METHODOLOGY}

This research was conducted in Kampar Kiri Community Health Center because there were many mental disorder patients and there were still more patients who were isolated by their family. This study began from February to June 2019. This study used a quantitative research design using cross sectional approach.

The population was the family of mental disorder patients in Kampar Kiri Community Health Center, with a total of 47 respondents. This study used total sampling technique where all family or those who are responsible for the treatment of mental patients in Kampar Kiri Health Center will became research sample consisting of 47 people.

The data were collected by using questionnaires for patients' family health beliefs about mental health and treatment seeking questionnaire that had tested for its validity and reliability. The analysis used is univariate and bivariate analysis. Univariate analysis describes the characteristics of respondents related to age, gender, education, occupation, and duration of mental illness. Bivariate analysis is used to determine there is a significant relationship between the two variables using chi-square test with the Kolmogorov Smirnov as alternative test.

\section{RESULTS}

\section{Univariate Analysis}

Table 1: Frequency Distribution of Characteristic Respondents $(N=47)$

\begin{tabular}{|c|c|c|}
\hline Characteristic & Frequency & Percentage (\%) \\
\hline \multicolumn{3}{|l|}{ Age } \\
\hline Early adolescent & 14 & 29.8 \\
\hline Late Adolescent (36-45 years old) & 17 & 36.2 \\
\hline Early Elderly (46-55 years old) & 11 & 23.4 \\
\hline Late elderly (56-65 years old) & 5 & 10.6 \\
\hline \multicolumn{3}{|l|}{ Gender } \\
\hline Male & 24 & 51.1 \\
\hline Female & 23 & 48.9 \\
\hline \multicolumn{3}{|l|}{ Education } \\
\hline Elementary school & 28 & 59.6 \\
\hline Junior high school & 12 & 25.5 \\
\hline Senior high school & 3 & 6.4 \\
\hline Associate degree & 1 & 2.1 \\
\hline Bachelor degree & 3 & 6.4 \\
\hline \multicolumn{3}{|l|}{ Occupation } \\
\hline Housewife & 12 & 25.5 \\
\hline Farmer & 24 & 51.1 \\
\hline Civil Cervant & 4 & 8.5 \\
\hline Private & 2 & 4.3 \\
\hline Entrepreneur & 5 & 10.6 \\
\hline \multicolumn{3}{|l|}{ Long suffered mental disorder } \\
\hline$<4$ years & 9 & 19.1 \\
\hline $4-10$ years & 22 & 46.8 \\
\hline$>10$ years & 16 & 34.0 \\
\hline
\end{tabular}

Table 2: Frequency Distribution of Respondent based on Mental Health Belief (N=47)

\begin{tabular}{|l|l|c|c|}
\hline No & Mental Health Belief & Total (n) & Percentage (\%) \\
\hline 1. & Supernatural & 29 & 61.7 \\
2. & Holisti c & 5 & 10.6 \\
3. & Scientific & 13 & 27.7 \\
\hline & Total & 47 & 100 \\
\hline
\end{tabular}

Based on the study results it is known that most respondent's mental health beliefs are supernatural, it is 29 respondents $(61.7 \%)$.

Table 3: Frequency Distribution of Respondent based on the First Action in Seeking Treatment $(N=47)$

\begin{tabular}{|l|l|c|c|}
\hline No & $\begin{array}{l}\text { The First Action In Seeking } \\
\text { Treatment }\end{array}$ & Total (n) & Percentage (\%) \\
\hline 1. & Health Facility & 22 & 46.8 \\
\hline 2. & Supranatural & 25 & 53.2 \\
\hline & Total & 47 & 100 \\
\hline
\end{tabular}




\section{Bivariate analysis}

The bivariate analysis in this study explains the relationship of patients' family beliefs about mental health to the first step in seeking treatment for mental disorders in Kampar Kiri Public Health Center using Chi-Square test with Kolmogorov Smirnov as alternative test.

\section{Table 4: ChiSquare Test}

The relationship of patients' family beliefs about mental health to the first step in seeking treatment for mental disorders $(N=47)$

\begin{tabular}{|c|c|c|c|c|}
\hline \multirow{2}{*}{$\begin{array}{c}\text { Mental } \\
\text { Health Belief }\end{array}$} & \multicolumn{2}{|c|}{ First Treatment } & Total & \multirow{2}{*}{ p value } \\
\cline { 2 - 4 } & $\begin{array}{c}\text { Health } \\
\text { Facility }\end{array}$ & $\begin{array}{c}\text { Supranat } \\
\text { ural }\end{array}$ & & \\
\hline Supernatural & $4(13,8 \%)$ & $25(86.2 \%)$ & $29(100 \%)$ & \multirow{2}{*}{0.000} \\
\hline Holistic & $5(100 \%)$ & $0(0 \%)$ & $5(100 \%)$ & \\
\hline Scientific & $13(100 \%)$ & $0(0 \%)$ & $13(100 \%)$ & \\
\hline \multicolumn{1}{|c|}{ Total } & $22(46,8 \%)$ & $25(53.2 \%)$ & $47(100 \%)$ & \\
\hline
\end{tabular}

Based on the results of chi-square test using Kolmogorov Smirnov Test as alternative test showed $p$ value $=0.000(p<0.05)$. It can be concluded that there is a significant relationship between patients' family beliefs about mental health towards the first act in seeking treatment for mental disorders in Kampar Kiri Health Center.

\section{DISCUSSION}

\section{Univariate Analysis}

\section{a. Respondent Characteristic}

Age is related to the level of maturity of a person. Siagian (2010) emphasized that the older you are, the more it could show the soul maturity and ability to think rationally, wisely, be able to control emotions and be open to the views of others.

According to Arifin (2011) gender can influence someone in providing interpretation of perception of an object or stimulus they see. Gender differences tend to form different perceptions that affect different attitudes between men and women in valuing an object.

According to Mubarak (2007) through education a person will learn many things, absorb a lot of information, change perceptions and form right understanding. The hight level of education make someone easier to receive information so it will improve their knowledge about health. Conversely, low education will be a barrier to improve new knowledge, especially in giving opinions to support patients with mental disorders.
Occupation can make a person gain experience and knowledge both directly and indirectly. Occupation is a factor that influence someone's perception and attitude. Someone who often interacts with other people will get more knowledge than people without any interaction with others (Foster, 2008).

According to Risna et al., (2017) when an individual is suffering from mental disorder then the family or community will isolate that person with mental disorder. The wrong behavior and treatment given by family will delay healing process of person with mental disorders.

\section{b. Mental Health Belief}

The results of 47 respondents in Kampar Kiri Community Health Center showed that most of the health belief is supernatural $(61.7 \%)$. The results of this study indicate that the people in Kampar Kiri Community Health Center still believe that mental disorders are due to spirits, witchcraft, and curse.

The results of this study are correlated with Lubis (2009) who found that in society there are beliefs or myths about mental disorders, some of them believe that mental disorders are caused by demons' spirits, witchcraft, curse or punishment for their sin. This belief will hurt the patients and family because people with mental disorders does not get right and quick treatment.

According to Ching \& Chen (2016) family of people with mental disorders believe that severe mental disorders are being associated with supernatural activities. The community belief that mental disorders are caused by evil spirits or witchcraft, which influenced family to seek help from non-medical treatment.

\section{c. The first action in seeking treatment for mental disorder}

The results of 47 respondents in Kampar Kiri Health Center revealed that in most of the cases the first step in seeking treatment for patient with mental disorder is supernatural treatment, that is 25 respondents $(53.2 \%)$.

Majority of the people in that area seek treatment from person apparently with supernatural ability because they still believed that mental disorders are caused by witchcraft, curse and other such phenomenon. This will have direct impact on the patients because their family only trust supernatural treatment. So, as a result the patient will not get proper treatment in mental hospital or from a psychiatrist. The family does not rely on formal treatment because mental health facilities are far from their home and expensive. Therefore the family 
prefers to isolate mental disorder patient by separating then in their own room/ house.

The results of this study are correlate with Masita's research (2019) about the relationship between family belief and behavior in seeking help for mental disorders patient in Ternate. It can be concluded that majority of respondent $(59.7 \%)$ will prefer to get treatment from person with supernatural ability than seeking the health facility (Puskesmas).

Kadafi's research (2014) in Sumedang about efforts to seek treatment for patients with severe mental disorder, showed that families seek treatment for severe mental disorders but lack of mental health knowledge force them to opt for traditional treatment. Due to this scenario patients suffering from mental disorder are generally get late medical treatment and consequently they feel helpless, lose social function, and are disconnected from their own family members.

\section{Bivariate Analysis}

The results of research in Kampar Kiri Community Health Center about the relationship between the family belief about mental health and the first act in seeking mental disorder treatment showed $p$ value $=0.000$ $(p<0.05)$. So, it can be concluded that there is a significant relationship between the patient's family beliefs about mental health with the first action in seeking treatment for mental disorders in Kampar Kiri Health Center.

The results of this study are correlate with Iseselo, Kajula \& Yahya-Malima (2016) and Mishra et al., (2011) about the relationship between family belief and the behaviorial pattern of treatment seeking for mental disorders in Ternate. According to the study conclusion there is a relationship between family belief with the treatment pattern for mental disorders with $p$ value $=0.000$. According to researcher family will prefer to get treatment from supernatural sources than going to health facility (Puskesmas). This is because the community thinks that mental disorders are caused by demon spirits or related to supernatural activities.

This is correlated with Lumongga (2016) regarding the understanding about mental disorder and mental healing delay. There is a belief in the community about mental disorders, some people believe mental disorders are caused by demon spirits, witchcraft, curse or sin. Family with mental disorders prefer to seek nonmedical treatment to treat the symptoms of mental disorders.
The results of this study are correlate with Funani \& Dewi (2014) about health belief model in supernatural alternative treatment. The perception of patients with alternative supernatural treatment starts from their belief in strange diseases. Different family backgrounds make different perceptions related to the treatment. The family reason to choose alternative supernatural treatment as the family belief depend on mental health, personal experience, medical cost, simple treatment methods and fast recovery.

According to Hawari (2014) The community belief about mental disorders are caused by witchcraft and curse. This impact their efforts to treat people with mental disorders. They will prefer paranormal treatment. In addition, there are many families who feel ashamed of the family member suffering from mental disorders, this cause family to hide and isolate patient with mental disorder.

According to Andrew (2008) all cultures have different beliefs. Theories about mental health and etiology of disease are based on community beliefs. This view includes attitudes, beliefs and health practices and it is usually known as the health belief system. This health believes influenced family to treat family member with mental disorder (Kadafi, 2014).

Subu (2015) in his research showed that families usually go for traditional and alternative therapies to treat mental disorders. The results showed that traditional and alternative therapies and smart people (shamans, Islamic religious leaders, priests, psychics and traditional Chinese medicine) have a central role in supporting and offering solutions when someone has a mental disorder in Indonesia. The therapist or 'smart person' is usually the first choice of family and other members of the community when it comes to therapy for people suffering from mental disorders. The community still believes that the disease is caused supernaturally.

This study is also correlate with James \& Peltzer (2012) in his research about Traditional and alternative therapy for mental illness in Jamaica. The study showed more than one third patients said mental illness is caused by supernatural causes, so patient commonly seek for treatment from tradional or alternative methods.

\section{CONCLUSIONS}

Univariate research results showed the majority of respondents were 36-45 years old (late adolescent) $(36.2 \%)$, male gender $(51.1 \%)$, last education graduated from elementary school $(59.6 \%)$, farmer occupation $(51.1 \%)$, suffered mental illness $4-10$ years 
$(46.8 \%)$, and analysis showed the majority of respondents believe that mental health is supernatural disease $(61.7 \%)$ with the first action in seeking treatment for mental disorders to the supernatural (53.2\%). The results of bivariate analysis showed $p$ value $(0.000)<\alpha(0.05)$, so it can be concluded that there is a significant relationship between patients' family beliefs about mental health towards the first action in seeking treatment for mental disorders in Kampar Kiri Health Center.

\section{REFERENCES}

Andrew, B. (2001). Variasi Agama di Jawa: Suatu Pendekatan Antropoogi $1^{\text {st }}$ Edition. Jakarta: Raja Grafindo Persada Arifin. (2011). Metode Penelitian Kualitatif, Kuantitatif dan R \& D. Bandung: Alfabeta.

Choudhry, F.R., Mani, V., Ming, L.C. \& Khan, T.M. (2016). Beliefs and perception about mental health issues: a metasynthesis. Neuropsychiatric Disease and Treatment, 12, pp 2807-2818.

Foster, B. (2008). Manajemen Ritel. Bandung Alfabeta.

Funani, S. \& Dewi, T.K. (2014). Health Belief Model pada Pasien Pengobatan Alternatif Supranatural dengan Bantuan Dukun. Journal Psikologis Klinis dan Kesehatan Mental, 3(1), pp 54-59.

Hawari, D.H. (2014). Skizofrenia Pendekatan Holistik (BPSS) Bio-Psiko-Sosial-Spiritual. Jakarta: Badan Penerbit Fakultas Kedokteran Universitas Indonesia.

James, C.C. \& Peltzer, K. (2012). Traditional and alternative therapy for mentalillness in Jamaica: patients' conceptions and practitioners' attitudes. African Journal of Traditional and Complement Alternative Medicine, 9(1), pp 94-104.

Kadafi, I. (2014). Upaya Pencarian Pengobatan Penderita Gangguan Jiwa Berat yang Mengalami Pemasungan di Sumedang. Journal Ilmu Kesehatan, 6(2).

Kirkby, K. C. (2017). Mechanical and Physical Restraint. Tasmania's Mental Health Act. https://www.dhhs.tas.gov.au

Lumongga, N. (2016). Depresi: Tinjauan Psikologis. Jakarta: Kencana Prenada Media Group.

Masita, S. (2019). Hubungan Kepercayaan Dengan Perilaku Mencari Pertolongan Pada Keluarga. Program Studi Ilmu Keperawatan Fakultas Kedokteran Univeristas Sam Ratulangi. Diakses 20 Februari 2019.

Masita, S., Buanasari, A. \& Silolonga, W. (2019). Hubungan Kepercayaan Dengan Perilaku Mencari Pertolongan Pada Keluarga Orang Dengan Gangguan Jiwa Di Kota Ternate. e-journal Keperawatan(e-Kp), 7(1).

Mubarak, I. (2007). Ilmu Kesehatan Masyarakat Konsep dan Aplikasi dalam Kebidanan. Jakarta: Salemba Medika.

Nasir, A. \& Muhith, A. (2015). Dasar-dasar Keperawatan Jiwa. Jakarta: Salemba Medika.

Risna, Mudatsir, Kamil, H., Jannah, S.R. \& Tahlil, T. (2017). Stigma Keluarga terhadap Penderita Skizofrenia Ditinjau dari Aspek Sosial Budaya dengan Pendekatan Sunrise Model. Prosiding Seminar Nasional Pascasarjana Unsyiah, pp 121-128.

Siagian, S.P. (2010). Manajemen Sumber Daya Manusia. Jakarta: Bumi Aksara.

Subu, M.A.(2015). Pemanfaatan Terapi Tradisional dan Alternatif oleh Penderita Gangguan Jiwa. Journal Keperawatan Padjadjaran, 3(3), pp 193-203.

Videbeck, S.L. (2011). Psychiatric Mental Health Nursing, ( $5^{\text {th }}$ ed). Lippincot Williams and Wilkins.

Wu, H.C. \& Chen, F.P. (2016). Sociocultural Factors Associated with Caregiver-Psychiatrist Relationship in Taiwan. Psychiatry investigation, 13(3), pp 288-296.

Yosep, I. (2011). Keperawatan Jiwa. Bandung: PT. Refika Aditama. 